\title{
Implementation of Financial Services Authority Regulation №35/POJK.05/2015 Article 35 by Indonesian Venture Capital Companies in 2015
}

\author{
iD AL AMIN, Eka Mulia Nurul ${ }^{a^{*}}$; (iD) HANIFUDDIN, Iza $b$ \\ a. Islamic Economics and Business Faculty, IAIN Ponorogo, Indonesia. Corresponding author (mulianaaeka@gmail.com) \\ b. Islamic Economics and Business Faculty, IAIN Ponorogo, Indonesia.
}

PUBLISHED: 26/11/2021

\section{COPYRIGHT NOTICE:}

(c) 2021 by authors. Licensee ERUDITUS. This article is an open access article distributed under the terms and conditions of the Creative Commons Attribution (CC BY) license (https://creativecommons.org/licenses/by/4.0/ ).

\section{CITE THIS PAPER:}

Al Amin, Eka Mulia Nurul; Hanifuddin, Iza (2021). " Implementation of Financial Services Authority Regulation №35/POJK.05/2015 Article 35 by Indonesian Venture Capital Companies in 2015" Journal of World Economy: Transformations \& Transitions (JOWETT) 1(02):08. DOI: https://doi.org/10.52459/jowett1281121

\section{ABSTRACT}

POJK or the Financial Services Authority Regulation is one of the official documents of the Indonesian government related to the state finance sector. Venture capital itself is one of the contributors to the economy of Indonesia, especially in terms of financing or equity participation. Therefore, regulations are needed to control the operation of venture capital businesses to avoid damages caused by problems/disruptions. Generally, the economic sector in Indonesia is highly regulated, and venture capital is not an exception. However, this paper only focuses on the analysis of the actual implementation of one of the venture capital regulations in Indonesia, namely POJK No. 35/POJK.05/2015 concerning equity participation in Venture Capital Companies (VCC), particularly, Article 35 which states that VCC must have a ratio of Equity to Paid-in Capital not less than 30\%. For this research, the method of qualitative normative approach has been applied based on the secondary data concerning Business Operations of Venture Capital Companies. The results of this research show fulfillment of these implemented regulations in practice by the existing VCC and its potential.

\section{KEYWORDS}

Venture Capital, Equity, Financial Regulation, Indonesia, VCC, POJK. 


\section{PRELIMINARY}

Venture capital has recently emerged as one of the industries that are widely targeted and favored by business actors in Indonesia, ranging from large entrepreneurs to start-up companies, Micro, Small, and Medium Enterprises (MSMEs). In the face of the Covid-19 pandemic, the continuous investment/financing of venture capital is also inextricably linked to the rapid digitalization of businesses, particularly e-commerce, fintech, edutech, healthtech, MSMEs, and start-up companies or startups. Nevertheless, in practice, opening or setting up a business requires a large amount of capital, and most prospective entrepreneurs lack sufficient capital to do that while usually are unable to get bank credits since do not have enough assets to be served as collateral. Furthermore, most of MSMEs find it difficult to use bank credits because of high interest rates, long-lasting process, and available amount of funds.

Venture capital can be a solution for both prospective entrepreneurs and MSME actors in terms of financing/capital participation in the form of equity participation, purchase of convertible bonds and/or distribution of business results carried out within a specific time frame. Venture Capital Companies (VCC) provide financing directly to companies that receive or are known as Business Partner Companies (investee company), thus it can be done quickly. Venture capital takes the risk of investing in a promising business, and in the long run, VCC anticipates high returns from investee company.

According to data from the Financial Services Authority (OJK) on 61 venture capital in Indonesia, the contribution of financing/capital participation reached Indonesian Rupiah (IDR) 15.82 trillion in June 2021. The financing for wholesale and retail trade, as well as car and motorcycle repair and maintenance, totaled IDR 5.89 trillion. Following that, financial and insurance activities totaling IDR 2.28 trillion, leasing and leasing activities without option rights totaling IDR 1.82 trillion, and employment, travel agents, and other business support activities totaling IDR 1.82 trillion. Looking back to 2015, the total amount of financing or venture capital participation was still IDR 6.88 trillion. This demonstrates that VCC's activities have grown significantly, as has its ability to support investee company funds.

VCC's activities, particularly investee companies' participation/financing, must, of course, be based on strong legal regulations governing the two parties' cooperation. One of the regulations for VCC is the Financial Services Authority Regulation, or POJK. On December 28, 2015, OJK issued POJK Number 34/POJK.05/2015 about Business Licensing and Institutional Venture Capital Companies, POJK Number 35/POJK.05/2015 relating to Business Operations for Venture Capital Companies, and POJK Number 36/POJK.05/2015 regarding Good Corporate Governance for Venture Capital Companies.

Previous research studies on similar topics include the work of Nurapipah (2017), aiming to discover the impact of the implementation of property financing, partnership procedures, and sharia economic law 
reviews on the implementation of property financing in Sharia venture investments based on POJK Number 35/POJK.05/2015. Then, based on Financial Services Authority Regulation No. 05/2015.35/POJK.05/2015, a proprietary study (Dukuy 2019) analyzes the implementation of venture capital financing agreements, particularly with profit sharing patterns and legal protection that Business Partners can obtain. Also, (Tanoto 2020) researched to determine the application of the precautionary principle in the practice of venture capital financing in Indonesia in accordance with Financial Services Authority Regulation 35/POJK.05/2015 concerning Business Operations of Venture Capital Companies and to determine the legal consequences on Business Partners who delay the provision of profit sharing to Venture Capital Companies under the Law of Agreement.

This paper attempts to analyze VCC from a different point of view - equity, since no previous research has addressed this issue, while it presents an important topic to examine the implementation of the legal regulations under the POJK No. 35/POJK.05/2015 2015 regarding the equity in Venture Capital Companies.

\section{LITERATURE REVIEW}

\subsection{Regulation of Venture Capital and POJK}

In Indonesia, venture capital was established by Presidential Decree Number 61 of 1988, dated December 20, 1988, concerning "Financing Institutions," which was followed by Decree of the Minister of Finance of the Republic of Indonesia (KMK) Number 1251/KMK.013/1988, also dated December 20, 1988. The document includes provisions and procedures. The financing company's line of business is further expanded to include Venture Capital, Securities Trading, Factoring, Credit Card Business, and Consumer Financing. Furthermore, the regulation of venture capital is governed by Ministry of Finance Regulation No. 469/KMK.17/1995 concerning the establishment and provision of venture capital (Kasmir 2014).

The Minister of Finance of the Republic of Indonesia (KMK) issued Decree Number 448/KMK.017/2000 dated 27 October 2000 concerning Financing Companies, and KMK Number 172/KMK.06/2002 dated 23 April 2002 concerning Amendments to KMK Number 448/KMK.017/2000, which was later changed to Minister of Finance Regulation (PMK) Number 84/PMK.012/2006 and venture capital and securities trading are no longer permissible. This arrangement was later reaffirmed in Presidential Regulation Number 9 of 2009 concerning Financing Institutions, dated March 18, 2009.

Until December 31, 2012, when the Ministry of Finance presented regulation and supervision of finance companies to the Financial Services Authority (OJK), several regulations, including financing companies, had been issued by OJK to make the financing industry stronger, more contributive, and inclusive. The Financial Services Authority has the power to regulate and supervise the activities of venture capital companies in Indonesia. Venture capital companies are specifically regulated by several laws and regulations (Siregar 2021). 
One of these financial regulations is the Financial Services Authority Regulation, or POJK, which governs various economic sectors in Indonesia.

POJK's position is based on Bank Indonesia's laws and regulations and the POJK №01/POJK.07/2013 is the first one issued by OJK, that aims to protect the interests of consumers in the financial services industry and the general public. For the time being, the most recent POJK issued is the POJK №51/POJK.03/2017, which relates to the Implementation of Sustainable Finance for Financial Service Institutions, Issuers, and Public Companies.

\subsection{Equity}

The definition of equity is stated in the Law of the Republic of Indonesia Number 1 of 2016, Article 13 Paragraph (1) Regarding Guarantee, which states that equity is the owner's right to the company's net assets (total assets minus liabilities). According to Statement of Financial Accounting Standards (PSAK) No.21 paragraph 2 of 2007, equity is defined as "the share of the owner's rights in the company in the form of the difference between existing and non-existing assets and liabilities, which is also a measure of the company's selling value." Based on this standard, equity is part of the owner's rights in the company, namely the difference between existing assets and liabilities, and is not a measure of the company's selling value (Khoriyah 2020). Then, according to (Kieso et al., 2014), equity is the residual ownership in the company's assets after all liabilities have been deducted. According to (Hadi and Ratnasari, 2013), equity is the difference between a company's total assets and total liabilities.

\subsection{Venture Capital}

Venture capital is a form of non-bank financial institution, which is an alternative financing method that offers more effective and efficient incentives in business development (Rangkuty and Zulmi, 2020). Venture Capital is a translation of the terminology in English. The venture itself means a business that contains risks so that often venture capital is interpreted as an investment that contains risks in a business or company which can be interpreted a business (Randiansyah and Nugroho, 2020). Venture capital, also known as equity participation, is a type of financing that aims to fund the establishment, development in the form of management advice, and participation in the company's strategy in both repairs and takeovers (equity participation) (Muliadi, 2013). The Presidential Decree No. 61 of 1988 defined the term "venture capital" as a business entity that provides financing to a company in the form of equity participation. It can also aid in management efforts and financial management. So that the company can become more efficient and effective in financial management and planning in the future. According to (Haspada et al., 2021), venture capital is a high-risk business that does not require collateral, so it requires the VCC's ability and willingness to manage and take risks in capital investments made to business-partner companies. This venture capital participation is very beneficial for the development 
of a business partner company (investee company) because it is provided without the need for guarantees, and VCC also assists investee company in the areas of management and marketing. Venture capital financing differs from working capital financing provided by bank loans in that venture capital financing business activities do not necessitate the provision of goods or guarantees (Sidik, 2017).

The nature of its activities in the form of direct capital participation, long-term capital participation (usually more than 3 years), entering a high-risk business, venture capital obtained either from capital gains, dividends, or profit-sharing, and its activities are more focused on the formation of new businesses. The goal of establishing venture capital is to: develop projects that are not solely for profit, invest in the development of new technologies that will earn profits in the long term, take over a company for profit, help financially weak entrepreneurs who do not have material guarantees, transform to new technologies in order to improve quality and production capacity, provide assistance in the establishment of new companies, and assist companies (Rangkuty and Zulmi, 2020).

For venture capital institutions in Indonesia, the concept of pure venture capital, such as venture capital companies abroad, is still not fully utilized. The current venture capital institutional structure does not distinguish between venture capital fund legal entities on the one hand and venture capital management on the other. Alternatively, the management of the pool of funds remains united with the management company. The provisions of the venture capital law do not apply any difference between the two types of structures. It is extremely difficult to raise funds for business development. In Indonesia, the only source of funds for venture capital companies is the paid-up capital of the company's shareholders (Novi t.t.). However, the potential for venture capital is still very open (Firdausy, 2018).

\subsection{Venture Capital Firm}

According to Article 1 №1 POJK/35/2015, venture capital business is capital participation or financing for a specific period of time to develop the business of a business partner or debtor. According to Article 2 paragraph (1) of POJK/35/2015, VCC engages in venture capital business, which includes equity participation, convertible bonds, debt securities financing, and productive business financing (FSA, 2016). A venture capital company is a business entity that conducts financing/investment business in a company that receives financing assistance (investment recipient company) for a specific period in the form of equity participation, participation through the purchase of convertible bonds, and/or financing based on the distribution of operating results. According to (Sidik, 2017), a Venture Capital Company (Venture Capital Company) is a business entity that carries out business financing/equity participation in a company that receives financing assistance (Investee Company) for a specific period in the form of equity participation, participation through the purchase of convertible bonds, and/or financing based on the distribution of operating results. Venture capital companies 
which according to regulations must be in the form of limited companies or cooperatives, but investee companies are not required to do so (Nurcahyo, 2016).

The establishment of PT Bahana Pembinaan Usaha Indonesia (BPUI) in 1973, based on government regulation №18 of 1973, was the history of the first venture capital company in Indonesia. The Ministry of Finance owns a majority stake in PT BPUI, a State-Owned Enterprise (BUMN). Finance has a stake of 88.2 percent, while Bank Indonesia has a stake of 17.8 percent (FSA, 2019). Then, in 1997, PT BPUI established PT Bahana Artha Ventura (PT BAV) with a loan of Indonesian Rupiah (IDR) 100 billion from the Ministry of Finance's Investment Fund Account (RDI) and a loan of 180 US dollars from Japan EXIM Bank (JEXIM). This is done to demonstrate the true impetus for the growth of venture capital in Indonesia. The Provincial Capital then established 27 Regional Venture Capital Companies (RVCC) to expand the financing reach of SME Venture Capital companies in the region. This establishment also aims to make the investee company's supervision and development easier. This establishment is the result of a collaboration between PT BAV, the Regional Development Bank (BPD), and local entrepreneurs. Paid-up capital from the establishment of RVCC is a minimum of Indonesian rupiah (IDR) 3 billion, and PT BAV becomes a shareholder in all RVCCs by contributing IDR 1 billion, or an average of 30-40 percent. PT. BAV is also obliged to provide management training regarding the management of Venture Capital companies.

\section{RESEARCH METHODS}

The analysis in this research employs a qualitative normative approach. The approach method is normative law, focusing on existing laws and regulations as positive law (Tanoto, 2020). Descriptive data, such as interview lists, reports on field observations, transcripts of conversations, and observation notes, are commonly used in qualitative research $($ Zaluchu, 2020). The data used in this paper is secondary data, including literature study materials / secondary data guided by POJK №35/POJK.05/2015 concerning Business Operations of Venture Capital Companies, as well as data from the Financial Services Authority and other parties relevant to this research. The development and growth of the Venture Capital Industry that is happening at this time began to apply the Financial Services Authority Regulation (POJK) on Venture Capital since 2015 (Kartono, 2020).

\section{DISCUSSION}

In 2015, VCC's business activities in Indonesia included financing through equity participation, the purchase of convertible bonds, and profit-sharing. IDR 6.89 trillion was recorded as the financing value. Profitsharing financing accounts for the most money, accounting for IDR 5.11 trillion (74.25 percent of total financing) (FSA, 2016). Following that, investments in shares totaling IDR 1.33 trillion and convertible bonds totaling IDR 434.39 billion were made. 
Finance activities in various economic sectors are also included in VCC. Among them are the agriculture, fishery, and forestry sectors of IDR 487.08 billion, the mining sector of IDR 539.97 billion, the industrial sector of IDR 344.86 billion, the construction sector of IDR 436.51 billion, the trade, restaurant, and hotel sector of IDR 1.89 trillion, the transportation and trade sector. and communication of IDR 1.59 trillion, business support services sector of IDR 345.67 billion, social and community services sector of IDR 1.006 trillion and other sectors of IDR 1.59 trillion. This year, the majority of VCC funding came from business entity/institutional loans totaling IDR 1.88 trillion. Furthermore, VCC obtained loans totaling IDR 665.70 billion from the Non-Bank Financial Industry, IDR 686.24 billion from banks, and IDR 269.32 billion in subordinated loans.

Table 1: Total Entities, Assets, Liabilities, Equity and Net Profit of Financing Institutions in 2015 (in Trillion IDR)

\begin{tabular}{llllll}
\hline Institution Type & Entity & Assets & Liability & Equity & Net Profit \\
\hline Financing Company & 203 & 425,71 & 329,70 & 96,01 & 10,67 \\
Venture Capital Company & 65 & 9,46 & 5,31 & 4,15 & 0,22 \\
Infrastructure Financing Company & 2 & 38,23 & 10,59 & 27,64 & 0,38 \\
\hline Amount & $\mathbf{2 7 0}$ & $\mathbf{4 7 3 , 4 0}$ & $\mathbf{3 4 5 , 6 0}$ & $\mathbf{1 2 7 , 8 0}$ & $\mathbf{1 1 , 2 7}$ \\
\hline
\end{tabular}

As shown in Table 1, made by author based on the Financial Institution Statistics 2015 (FSA, 2016), the contribution of VCC to the financing industry market in 2015 was still significantly lower than that of financing companies and infrastructure financing companies. This is evident from the assets held by the three institutions, which show a significant disparity in numbers. VCC's assets are only around IDR 9.46 trillion, compared to IDR 425.71 trillion and IDR 38.23 trillion for financing companies and infrastructure financing companies, respectively. However, the number of VCCs in 2015 was 65 , which is more than the Infrastructure Financing Company, which has only two. Although, at the end of 2015, the number of VCCs conducting conventional business activities decreased to only 61 companies (FSA, 2016).

\subsection{Implementation of POJK №35/POJK.05/2015 Article 35}

POJK №35/POJK.05/2015 concerning Business Operations of Venture Capital Companies is one of the regulations included in the regulatory package related to Venture Capital Companies (VCC) set by the Chairman of the OJK Board of Commissioners on December 21, 2015 and promulgated on December 28, 2015. This regulation includes general provisions, venture capital business, business activity agreement, business soundness level, equity, funding sources, venture funds, venture capital business for micro, small, medium, and cooperative businesses, prohibitions, periodic reports, information systems and technology, enforcement of compliance, sanctions, transitional provisions, and closing provisions. Article 35 of this regulation is included in CHAPTER V EQUITY and states that VCC or VCCs must have a ratio of Equity to Paid-in Capital of at 
least 30\% (thirty percent). And the funding sources are discussed in the next chapter, namely CHAPTER VI FUNDING SOURCES.

Table 2: Data on Equity of Indonesian Venture Capital Companies for the Period January - June 2015 (in Billion IDR)

\begin{tabular}{lllllll}
\hline Equity & January & February & March & April & May & June \\
\hline Paid-up capital & 2.298 & 2.286 & 2.273 & 2.265 & 2.285 & 2.281 \\
Agio (Disagio) & 131 & 131 & 131 & 131 & 131 & 131 \\
Reserve & 159 & 158 & 165 & 164 & 163 & 163 \\
Retained earning & 993 & 1.016 & 1.120 & 1.102 & 1.101 & 1.181 \\
Income for the year & 6 & 10 & 30 & 43 & 25 & 80 \\
$\begin{array}{l}\text { Other equity } \\
\text { components }\end{array}$ & $(10)$ & $(13)$ & $(13)$ & $(15)$ & $(16)$ & $(16)$ \\
\hline TOTAL EQUITY & 3.576 & 3.588 & 3.706 & 3.689 & 3.690 & 3.819 \\
\hline
\end{tabular}

Table 3: Data on Equity of Indonesian Venture Capital Companies for the Period of July - December 2015 (in Billion IDR)

\begin{tabular}{lllllll}
\hline Equity & July & August & September & October & November & December \\
\hline Paid-up capital & 2.281 & 2.281 & 2.282 & 2.269 & 2.279 & 2.397 \\
Agio (Disagio) & 131 & 131 & 131 & 131 & 131 & 131 \\
Reserve & 162 & 162 & 167 & 166 & 165 & 168 \\
Retained earning & 1.167 & 1.161 & 1.161 & 1.159 & 1.162 & 1.154 \\
$\begin{array}{l}\text { Income for the year } \\
\text { Other equity }\end{array}$ & 96 & 114 & 203 & 199 & 213 & 225 \\
components & $(17)$ & $(18)$ & $(17)$ & $(18)$ & $(18)$ & $(17)$ \\
\hline TOTAL EQUITY & $\mathbf{3 . 8 2 1}$ & $\mathbf{3 . 8 3 0}$ & $\mathbf{3 . 9 2 6}$ & $\mathbf{3 . 9 0 6}$ & $\mathbf{3 . 9 3 2}$ & $\mathbf{4 . 0 5 8}$ \\
\hline
\end{tabular}

According to the data above in Tables 2 and 3, made by authors based on the Summary of Financial Data for Venture Capital Companies (FSA, 2015), total VCC equity in Indonesia in 2015 ranged from IDR 3,576 billion in January to IDR 4,058 billion in December. Following Article 35, which states that the equityto-paid-in-capital ratio must be at least $30 \%$, the monthly details are as follows:

1. In January, the total paid-up capital was IDR 2,298 billion, the minimum equity that must be met was IDR 689.4 billion and in the data above, the equity reached IDR 3,576 billion.

2. In February, the total paid-up capital was IDR 2,286 billion, so the minimum equity that must be met was IDR 685.8 billion and in the data above, the equity reached up to IDR 3,588 billion.

3. In March, the total paid-up capital was IDR 2,273 billion, the minimum equity that must be met was IDR 681.9 billion and in the data above, the equity reached IDR 3,706 billion. 
4. In April, the total paid-up capital was IDR 2,265 billion, the minimum equity that must be met was IDR 679.5 billion and in the data above, the equity reached up to IDR 3,689 billion.

5. In May, the total paid-up capital was IDR 2,285 billion, the minimum equity that must be met was IDR 685.5 billion and in the data above, the equity reached up to IDR 3,690 billion.

6. In June, the total paid-up capital was IDR 2,281 billion, so the minimum equity that must be met is IDR 684.3 billion and in the data above, the equity is up to IDR 3,819 billion.

7. In July, the total paid-up capital was IDR 2,281 billion, so the minimum equity that must be met is IDR $684.3 \mathrm{M}$ and in the data above the equity reaches up to IDR 3,821 billion.

8. In August, the total paid-up capital was IDR 2,281 billion, so the minimum equity that must be met is IDR 684.3 billion and in the data above, the equity is up to IDR 3,830 billion.

9. In September, the total paid-up capital was IDR 2,265 billion, so the minimum equity that must be met was IDR 679.5 billion and in the data above, the equity reached up to IDR 3,689 billion.

10. In October, the total paid-up capital was IDR 2,269 billion, the minimum equity that must be met was IDR 680.7 billion and in the data above, the equity reached up to IDR 3,906 billion.

11. In November, the total paid-up capital was IDR 2,279 billion, so the minimum equity that must be met is IDR 683.7 billion and in the data above, the equity is up to IDR 3,932 billion.

12. In December, the total paid-up capital was IDR 2,397 billion, so the minimum equity that must be met is IDR 719.1 billion and in the data above, the equity is up to IDR 4,058 billion.

In practice, VCC's average paid-up capital from January to December 2015 was IDR 2,289 billion. The average amount of equity required by venture capital firms during that period was 687 billion Indonesian rupiahs. VCC attained IDR 3,795 billion.

\section{CONCLUSION}

After looking at various sources and conducting an analysis, it can be concluded that the implementation of regulations related to the venture capital businesses, especially regarding equity in POJK №35/POJK.05/2015 Article 35 in Indonesia has been fulfilled well and even maximally by VCC in 2015. Although the average amount of required equity was IDR 687 billion, in practice, VCC managed to have equity five times greater than the minimum limit amounting up to IDR 3,795 billion. This proves that in the examined year VCCs were able to maximize their use as a financier or equity participant for business development and have a great 
potential. In the future, VCCs must continue to improve their management, quality of working and company funding so that more parties or business partners are assisted in terms of capital, beginning with small businesses, and progressing to large corporations, thus, synergy can be built for making possible participation in the flow of the Indonesian economy. The author believes that the results of this research may be served as a comparison basis by other researchers to examine the functionality of VCCs in the most recent periods where new findings can be made.

FUNDING: The authors did not receive any external funding.

CONFLICT OF INTEREST: The authors declare no conflicts of interest.

\section{REFERENCES}

1. Dukuy, Calvariana Aruds, 2019. Pelaksanaan Perjanjian Modal Ventura Antara PT Srana Kalteng Ventura dan Tri Akbar Samsi Silam Ditinjau Berdasarkan Peraturan Otoritas Jasa Keuangan Nomor 35/POJK.05/2015 tentang Penyelenggaraan Usaha Perusahaan Modal Ventura. Thesis, Bandung: Universitas Padjadjaran, 2019. Available at: https://repository.unpad.ac.id/frontdoor/index/index/year/2020/docId/2990

2. Firdausy, Carunia Mulya, 2018. Peran Industri Keuangan Non Bank terhadap Perekonomian Indonesia. Jakarta: Yayasan Pustaka Obor Indonesia. ISBN 978-602-433-711-7. YOI: 1600.36.154.2018

3. FSA, 2015. Financial Services Authority: Financial Data Summary of Venture Capital Companies January-December 2015.

4. FSA, 2016. Financial Service Authority: Statistics of Financing Institutions 2015. Jakarta: Financial Services Authority.

5. FSA, 2019. Financial Services Authority: Financial institutions. Jakarta: Financial Services Authority, 2019.

6. Hadi, Putu Sofya; Ratnasari, Maria M., 2013. "Analisis Pengaruh Ekuitas Wajib Pajak Badan pada Beban Pajak Penghasilan." E-Jurnal Akutansi Universitas Udayana, 378-387. Available at: https://simdos.unud.ac.id/uploads/file_penelitian_1_dir/54e434440e83c62ec8f68ae997f0b0 1e.pdf

7. Haspada, G. P.; Abubakar, L.; Lubis, N. A., 2021. Pencantuman Klausul Jaminan dalam Usaha Modal Ventura Ditinjau dari Peraturan Otoritas Jasa Keuangan Nomor 35/Pojk. 05/2015 
Tentang Penyelenggaraan Usaha Perusahaan Modal Ventura. ACTA DIURNAL Jurnal Ilmu Hukum Kenotariatan, 4(2), 263-278. DOI https://doi.org/10.23920/acta.v4i2.559 Available at: http://jurnal.fh.unpad.ac.id/index.php/acta/article/view/559

8. Kartono, K., 2020. Kinerja Perusahaan Modal Ventura Diukur dari Sisi Rasio Beban Operasi terhadap Pendapatan Operasi Rasio Investasi Terhadap Total Aset Return on Asset dan Non Performing Finance (Studi Kasus Pada PT. Sarana Jakarta Ventura). Jurnal SEKURITAS (Saham, Ekonomi, Keuangan dan Investasi), 3(2), 122-131.

DOI: http://dx.doi.org/10.32493/skt.v3i2.4277 Available at: http://openjournal.unpam.ac.id/index.php/SKT/article/view/4277

9. Kasmir, 2014. Bank dan Lembaga Keuangan Lainnya. Jakarta: PT. Raja Grafindo Persada. ISBN: 978-979-769-413-5.

10. Khoriyah, Ulfatul, 2020. "Manajemen Ekuitas: Ekuitas Pemegang Saham dalam Perseroan." Repository Universitas Muhammadiyah Sidoarjo. April 9, 2020. http://eprints.umsida.ac.id/id/eprint/6746.

11. Kieso, Donald E; Weygandt, Jerry J.; Warfield, Terry D. 2010. Intermediate Accounting. IFRS Edition. Second Edition. USA: John Wiley \& Sons, Inc, 2014. ISBN-13 978-0470-61630-7.

12. Muliadi, Ahmad, 2013. Hukum Lembaga Pembiayaan. Jakarta: Kademia. ISBN 6028381578.

13. Nurapipah, Ipah, 2017. Tinjauan Hukum Ekonomi Syariah Terhadap Pembiayaan Property di Investama Ventura Syariah Bandung Dihubungkan dengan POJK Nomor 35/POJK.05/2015. Thesis, Bandung: Universitas Islam Negeri Sunan Gunung Djati Bandung, 2017. Available at: http://digilib.uinsgd.ac.id/6408/4/4_bab1.pdf

14. Nurcahyo, E., 2018. Perlindungan Hukum Kerjasama PT. Sarana Jateng Ventura dengan Perusahaan Pasangan Usaha dalam Pemberian Modal Ventura.

DOI https://doi.org/10.31227/osf.io/nx5ay Available at: https://osf.io/preprints/inarxiv/nx5ay/

15. Novi, Amanita. t.t. "Bank dan Lembaga Keuangan Lain." Modal Ventura. http://staffnew.uny.ac.id/upload/132318570/pendidikan/modal-ventura.pdf

16. Otoritas Jasa Keuangan, 2015. Ikhtisar Data Keuangan Perusahaan Modal Ventura Periode Januari-Desember 2015.

17. Randiansyah; Nugroho, G. W., 2020. Analisis Risiko Pembiayaan Pada Modal Ventura (Study Kasus Pada PT Bina Artha Ventura Cabang Cicurugg). Jurnal Syntax Admiration, 1(7), 911916. Available at: https://jurnalsyntaxadmiration.com/index.php/jurnal/article/view/106

18. Rangkuty, D. M.; Zulmi, A., 2020. Perbandingan Modal Ventura Konvensional dan Syariah: Studi Literatur Model Pembiayaan Startup dan UMKM di Provinsi Sumatera Barat. Ekonomi, Keuangan, Investasi Dan Syariah (EKUITAS), 1(2), 74-78. Available at: http://ejurnal.seminarid.com/index.php/ekuitas/article/view/65 
19. Sidik, Jafar, 2017. "Peran Strategis Modal Ventura Bagi UMKM dalam Menunjang Pembangunan Perekonomian Nasional Indonesia." Jurnal SIKAP (Sistem Informasi, Keuangan, Auditing dan Perpajakan), 120-133. Available at: https://core.ac.uk/download/pdf/286345951.pdf

20. Siregar, M. M. T., 2021. Investasi Modal Ventura Asing Kepada Start-Up Company (Perusahaan Rintisan) di Indonesia. Jurist-Diction, 4(4), 1567-1582. Available at: https://ejournal.unair.ac.id/JD/article/view/28487

21. Tanoto, Damario, 2020. Penerapan Prinsip Kehati-Hatian (Prudential Principle) dalam Kegiatan Usaha Modal Ventura Berdasarkan Peraturan Otoritas Jasa Keuangan Nomor 35/POJK.05/2015 tentang Penyelenggaraan Usaha Perusahaan Modal Ventura. Thesis, Bandung: Universitas Padjadjaran, 2020. Available at: https://repository.unpad.ac.id/frontdoor/index/index/year/2020/docId/3121

22. Zaluchu, S. E., 2020. STRATEGI PENELITIAN KUALITATIF DAN KUANTITATIF DI DALAM PENELITIAN AGAMA. Evangelikal: Jurnal Teologi Injili dan Pembinaan Warga Jemaat, 28-38. Available at: https://core.ac.uk/download/pdf/296974333.pdf 